\title{
Tularaemia in a brown hare (Lepus europaeus) in 2013: first case in the Netherlands in 60 years
}

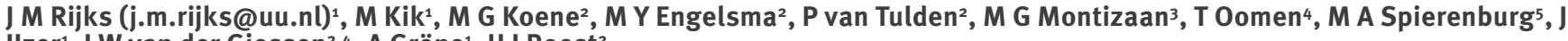
IJzer ${ }^{1}$, J W van der Giessen ${ }^{2,4}$, A Gröne ${ }^{1}$, H J Roest ${ }^{2}$

1. Dutch Wildlife Health Centre, Utrecht University, Utrecht, the Netherlands

2. Department of Bacteriology and TSEs, Central Veterinary Institute, part of Wageningen UR, Lelystad, the Netherlands

3. Royal Dutch Hunters Association, Amersfoort, the Netherlands

4. National Institute for Public Health and the Environment, Bilthoven, The Netherlands

5. Netherlands Food and Consumer Product Safety Authority, Utrecht, the Netherlands

Citation style for this article:

Rijks JM, Kik M, Koene MG, Engelsma MY, van Tulden P, Montizaan MG, Oomen T, Spierenburg MA, IJzer J, van der Giessen JW, Gröne A, Roest HJ. Tularaemia in a brown hare (Lepus europaeus) in 2013: first case in the Netherlands in 6o years. Euro Surveill. 2013;18(49):pii=20655. Available online: http://www.

eurosurveillance.org/ViewArticle.aspx?Articleld=20655

Article submitted on 23 November 2013 / published on 05 December 2013

Tularaemia has not been reported in Dutch wildlife since 1953. To enhance detection, as of July 2011, brown hares (Lepus europaeus) submitted for postmortem examination in the context of non-targeted wildlife disease surveillance, were routinely tested for tularaemia by polymerase chain reaction (PCR). Francisella tularensis subspecies holarctica infection was confirmed in a hare submitted in May 2013. The case occurred in Limburg, near the site of the 1953 case. Further surveillance should clarify the significance of this finding.

We report a brown hare (Lepus europaeus) infected with Francisella tularensis, the bacterium causing tularaemia, in the Netherlands in May 2013. This is the first case of tularaemia in Dutch wildlife since 1953. The finding results from the intensified surveillance of the disease in brown hares, which started in July 2011 after infected hares were detected in neighbouring countries.

Tularaemia, caused by the bacterium $F$. tularensis, is a zoonotic disease that was reported in more than 800 humans in the European Union in 2010 [1]. The bacterium has a very wide host range that includes mammals, birds, amphibians, fish, and invertebrates [2]. It can remain infectious in water and mud for months [3]. It can be transmitted by inhalation of infective aerosols, contact with or ingestion of infected hosts or water, and arthropod bites [2].

Four subspecies can be distinguished: tularensis, holarctica, mediasiatica and novicida. The first two subspecies are important causes of tularaemia in humans and animals [2]. The bacterium has been detected in wildlife in various European countries, such as Denmark, Finland, France, Germany, Spain, Sweden and Switzerland in 2012; Belgium, Italy and Norway in 2011; and Austria in 2009 (Figure 1) [4].
Lagomorphs and rodents are most susceptible to infection and disease by the bacterium [5]. In a number of European countries, brown hares are considered to be an important host of $F$. tularensis and transmission to humans is known to result from direct contact with hares $[6,7]$.

In the Netherlands, the agent was last reported in 1953 when seven members of an eight-person family became ill after consuming a brown hare [8,9]. In contrast, in Lower Saxony, a German federal state that shares a common border with the Netherlands, F. tularensis has been detected in $2.9 \%$ of hares found dead as recently as in the period between 2006 and 2009 [10]. In addition, in the autumn of 2011 tularaemia was found in hares in Düren, a municipality in North RhineWestphalia, Germany, about $50 \mathrm{~km}$ from the eastern Dutch border [11], as well as in Anthisnes, a municipality in the Province of Liege, Belgium, approximately at the same distance from the southern Dutch border [12].

These recent reports suggested that $F$. tularensis may also be present in the Netherlands without being detected. Therefore the Dutch Wildlife Health Centre (DWHC) and the Central Veterinary Institute (CVI) in collaboration with the National Institute for Public Health and the Environment (RIVM) decided to intensify surveillance for tularaemia in brown hares in the Netherlands.

\section{Finding of a brown hare testing positive for Francisella tularensis}

Brown hares that are found either dead or terminally ill and then euthanised by hunters or game wardens can be submitted to the DWHC for post-mortem examination in the context of non-targeted surveillance. Since July 2011, these hares have been routinely tested for the presence of $F$. tularensis DNA by polymerase chain reaction (PCR) at CVI. DNA was extracted from lung and/or spleen using a DNA tissue kit (DNeasy Blood and Tissue Kit; Qiagen, Hilden, 


\section{FIGURE 1}

Cases of tularaemia in animals in some European Union Member States, Croatia, Iceland, Norway and Switzerland, 2006-2012 ( $\mathrm{n}=19$ countries)

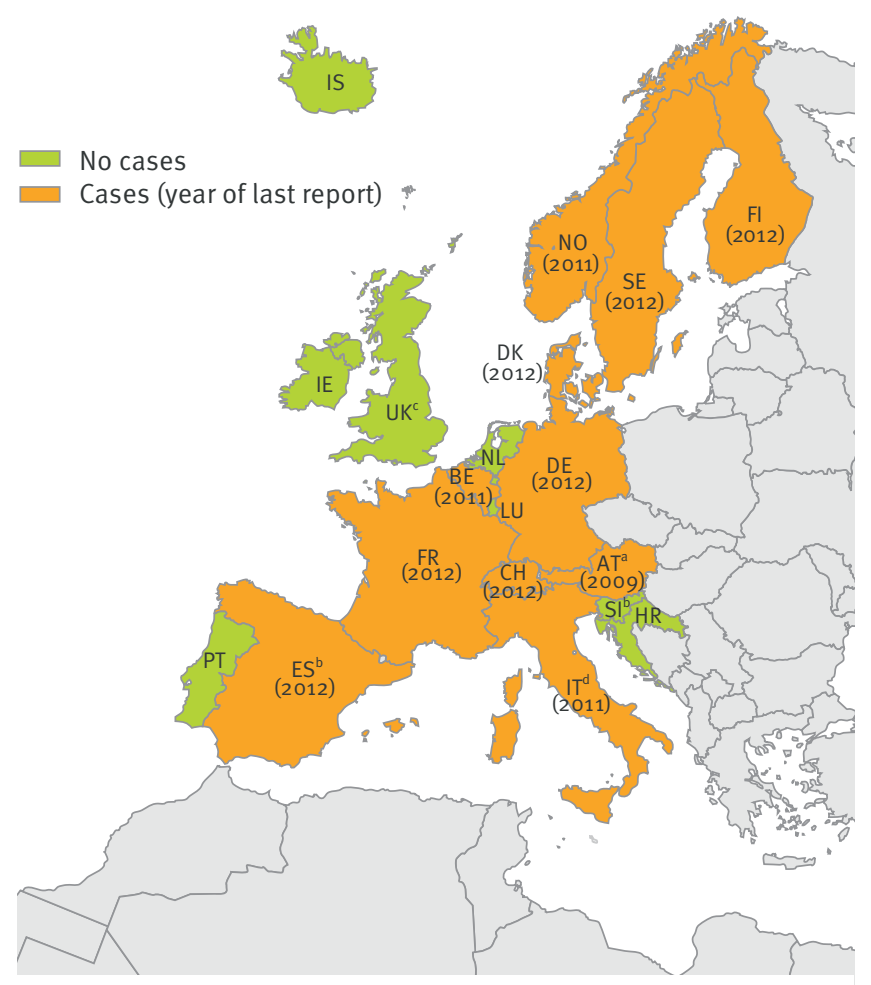

AT: Austria; BE: Belgium; CH: Switzerland; DE: Germany; DK: Denmark; ES: Spain; FI: Finland; FR: France; HR: Croatia; IE: Ireland; IS: Iceland; IT: Italy; LU: Luxembourg; NL: Netherlands; NO: Norway; PT: Portugal; SE: Sweden; SI: Slovenia; UK: United Kingdom.

a No information on the occurrence of tularaemia in animals was provided to the World Animal Health Information Database (WAHID) for AT before and after the year 2009.

b No information on the occurrence of tularaemia in animals was provided to WAHID for ES and SI in 2006.

No information on the occurrence of tularaemia in animals was provided to WAHID for the UK for 2006 to 2007.

d No information on the occurrence of tularaemia in animals was provided to WAHID for IT for 2006 to 2008 .

Source: The map was compiled based on information from the WAHID accessed on 20 August 2013.

Germany). The extracted DNA was tested by TaqMan real-time PCR using the FTT0376 primers and probe published by Mitchell et al. [13] (forward primer 5'-CCATATCACTGGCTTTGCTAGACTAGT-3', reverse primer 5'-TGTTGGCAAAAGCTAAAGAGTCTAAA-3', probe 5'-FAMAAATTATAAAACCAAACCCAGACCTTCAAACCACABHQ1-3'). This assay is specific for the pathogenic subspecies of $F$. tularensis (subspecies tularensis, holarctica and mediasiatica). The positive samples were also sent to the Swedish Veterinary Institute (SVA), Uppsala, Sweden for confirmation.
By May 2013 a total of 49 animals from nine of the 12 Dutch provinces had been examined (Figure 2). Of the 49 specimens, 26 had one or more macroscopic or microscopic lesions consistent with tularaemia in this species [14]. The first 48 hares tested negative for the presence of $F$. tularensis DNA by PCR. The 49th hare examined in May 2013 was an adult male hare from the province of Limburg. Prior to death, the animal had been seen with an unsteady gait, had been reluctant to move and was easy to catch.

The slightly autolytic carcass of this animal had an enlarged spleen at necropsy and histopathology revealed multiple foci of hepatocellular necrosis, consistent with F. tularensis infection [14]. Real-time PCR analyses of spleen and lung samples of this specimen were positive for $F$. tularensis. Culture of the samples from this animal on chocolate agar medium with cysteine and sodium sulphite provided negative results. Infection by $F$. tularensis was confirmed at the SVA, both by PCR (spleen) and immunohistochemistry (lung). The subspecies of $F$. tularensis was subsequently typed by CVI as holarctica based on the concatenated partial sequences of five metabolic housekeeping genes as described by Nübel et al. [15].

\section{Discussion and conclusion}

F. tularensis ranks among the top twenty emerging zoonotic pathogens considered to be relevant for the Netherlands [16]. The emergence or re-emergence of the disease in other countries has been associated with factors such as climate change, human-mediated movement of infected animals, as well as with conditions of war with subsequent increase in rodent populations. In some cases, detection due to enhanced surveillance revealed the presence of the disease $[2,17]$. Enhanced surveillance also likely contributed to the apparent re-emergence of tularaemia in Dutch wildlife after 60 years, as reported here.

The subspecies $F$. tularensis holarctica detected in this study is consistent with the subspecies detected in wildlife in the neighbouring countries [10]. The infected hare was found only $6 \mathrm{~km}$ away from the home of the family in the 1953 report [8,9] (Figure 2). It is unclear as to how widespread the occurrence of the bacterium is in wildlife in the Netherlands and therefore whether the proximity of both events indicates a hot spot or a coincidence. Heightened surveillance is needed in order to answer this question.

Given the proximity of these cases to the border, emergence due to import of the disease from neighbouring countries should also be considered. Indeed, in $\mathbf{2 0 1 2}$ four cases of tularaemia in hares were identified in the area of Heinsberg, Hückelhoven and Erkelenz in Germany, $10 \mathrm{~km}$ from the Dutch border and $30 \mathrm{~km}$ from the case reported here [18]. It is unlikely that hares are deliberately introduced from abroad into the Netherlands, since release of hares is illegal. It is also unlikely that the specific hare found infected in this 


\section{FIGURE 2}

Location and year of sampling of hares with polymerase chain reaction test results for Francisella tularensis $(\mathrm{n}=49)$ relative to where an infected hare was found in 1953, Netherlands, 2011-2013

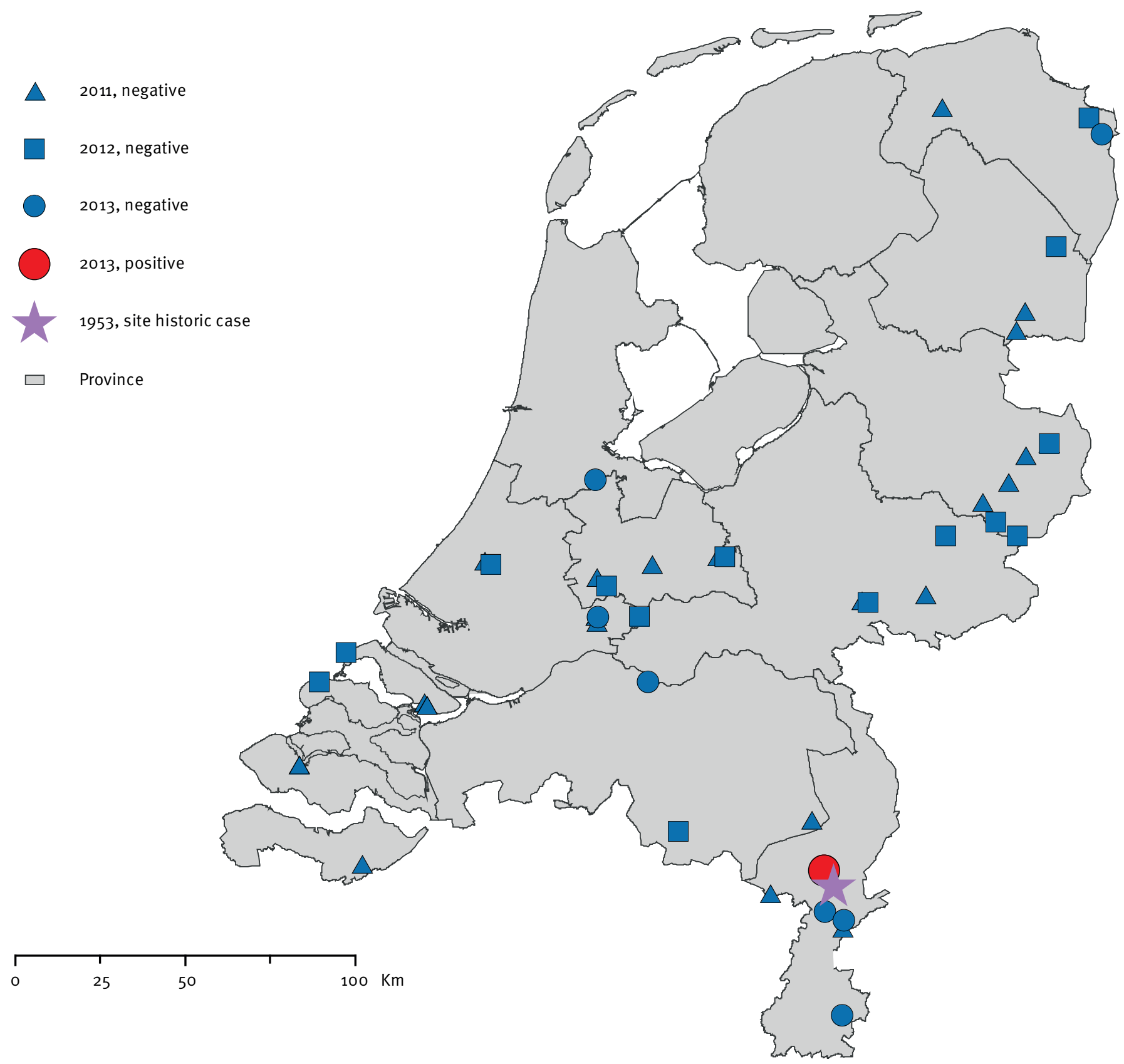

In the legend, the terms 'negative' and 'positive' are used to describe the sampled hares' polymerase chain reaction test results for Francisella tularensis.

study came from abroad on its own, as hares do not usually cover such distances and in addition, a large river separates the two locations $[19,20]$. However, the infection may have moved more gradually into the Dutch area through other hosts or vectors or both without having been detected.

Only two human tularaemia cases likely to be autochthonous have been recorded in the Netherlands since
1953, though human infection was notifiable from 1976 to $1999[9,21,22]$. One case occurred in 2011 and one in 2013 , and neither had a history of contact with dead hares or other animals [21,22]. However, it is presumed that the 2013 case may have contracted the disease in Limburg through insect bites [22]. Both, these human cases and the hare case, highlight the importance of raising the awareness of physicians and veterinarians with regards to the disease. 
These findings support the continuation of non-targeted disease surveillance in hares and other wildlife species, and heightened targeted surveillance for tularaemia, with focus on the affected regions. Hunters, game wardens, and other groups that are likely to come into close contact with wildlife will be informed and included in these activities.

\section{Acknowledgements}

The authors thank $Y$ Bisselink, $R$ Ruuls, $N$ Buijs, and $M$ Buitelaar for technical and administrative assistance, SVA for confirmation testing by PCR and immunohistochemistry, and R Thomas for her suggestions for textual corrections. Funding statement: Non-targeted surveillance of wildlife in the Netherlands was funded by the Faculty of Veterinary Medicine of Utrecht University, the Dutch Ministry of Economic Affairs and the Dutch Ministry of Health, Welfare and Sport. Laboratory testing at CVI was primarily financed by the Ministry of Economic Affairs through the project 'meldingsplichtige ziekten', grant number WOT-01-002-05.02. Confirmation at SVA was funded by the Wildtech project (EU 7th Framework Program for Research and Technological Development, grant agreement no. 222633).

\section{Conflict of interest}

None declared.

\section{Authors' contributions}

JMR, MGM, JWvdG, TO, MAS, AG, HJR were involved in the surveillance set-up and its general implementation. MK and IIJ performed the post-mortem examinations; PVT, MYE and MGK the diagnostic tests. JMR, AG, MYE and HJR drafted the manuscript, and MK, MGK, PvT, MGM, JIJ and JWvdG critically revised it. JMR provided figures 1 and 2. All authors approved the final version of the manuscript.

\section{References}

1. European Centre for Disease Prevention and Control (ECDC). Annual Epidemiological Report 2012. Reporting on 2010 surveillance data and 2011 epidemic intelligence data. Stockholm: ECDC; 2013; p 119. Available from: http:// ecdc.europa.eu/en/publications/Publications/AnnualEpidemiological-Report-2012.pdf

2. Petersen JM, Schriefer ME. Tularemia: emergence/reemergence. Vet Res. 2005;36(3):455-67. http://dx.doi.org/10.1051/vetres:2005006 PMid:15845234

3. Parker RR, Steinhaus EA, Kohls GM, Jellison WL. Contamination of natural waters and mud with Pasteurella tularensis and tularemia in beavers and muskrats in the northwestern United States. Bull Natl Inst Health. 1951;193:1-161. PMid:14869929

4. World Animal Health Information Database (WAHID). Country information, Animal health situation. Paris: World Organisation for Animal Health. [Accessed 20 Aug 2013]. Available from: http://www.oie.int/wahis_2/public/wahid.php/ Countryinformation/Animalsituation

5. Hopla CE. The ecology of tularemia. Adv Vet Sci Comp Med. 1974;18(0):25-53. PMid:4419176

6. Decors A, Lesage C, Jourdain E, Giraud P, Houbron P, Vanhem P, et al. Outbreak of tularemia in brown hares (Lepus europaeus) in France, January to March 2011. Euro Surveill. 2011; 16(28): pii=19913. Available from: http://www.eurosurveillance.org/ ViewArticle.aspx?Articleld $=19913$

PMid:21794224

7. Schätzle W, Schwenk R. Three cases of tularaemia in southern Baden-Wuerttemberg, Germany, November 2007. Euro Surveill. 2008;13(7): pii=8037. Available from: http://www.
eurosurveillance.org/ViewArticle.aspx?Articleld =8037 PMid:18445420

8. Hemmes GD. Tularaemie te Horn. [Tularaemia at Horn]. Ned Tijdsch v Geneesk. 1953;97(16):990-2. Dutch.

9. Warris-Versteegen AA, van Vliet JA. De naoorlogse geschiedenis van tularemie. [The postwar history of tularemia]. Infectieziekten Bulletin. 2003;14(5):182. Dutch.

10. Runge $M$, von Keyserlingk M, Braune S, Voigt U, Grauer A, Pohlmeyer K, et al. Prevalence of Francisella tularensis in brown hare (Lepus europaeus) populations in Lower Saxony, Germany. Eur J Wildl Res. 2011;57:1085-9. http://dx.doi.org/10.1007/s10344-011-0522-1

11. Animal Health Online (AHO). Kreis Düren: Fall von Hasenpest bei einem Feldhasen. [Düren county: a case of tularemia in a hare]. German. [Accessed 18 Aug 2013]. Available from: http://www.animal-health-online.de/klein/2011/10/17/ kreis-duren-fall-von-hasenpest-bei-einem-feldhasen/7773/

12. Grégoire F, Volpe R, Linden A. Disease surveillance (2010-2011) in hares in Southern Belgium. Liège: Surveillance network of Wildlife Diseases, Faculty of Veterinary Medicine, University of Liege; 2012;7-8.

13. Mitchell JL, Chatwell N, Christensen D, Diaper H, Minogue TD, Parsons TM, et al. Development of real-time PCR assays for the specific detection of Francisella tularensis ssp. tularensis, holarctica and mediaasiatica. Mol Cell Probes. 2010;24(2):726. http://dx.doi.org/10.1016/j.mcp.2009.10.004 PMid:19833196

14. Gyuranecz M, Szeredi L, Makrai L, Fodor L, Mészáros AR, Szépe B, et al. Tularemia of European brown hare (Lepus europaeus): a pathological, histopathological, and immunohistochemical study. Vet Pathol. 2010;47(5):958-63. http://dx.doi.org/10.1177/0300985810369902 PMid:20466857

15. Nübel U, Reissbrodt R, Weller A, Grunow R, Porsch-Ozcürümez $\mathrm{M}$, Tomaso $\mathrm{H}$, et al. Population structure of Francisella tularensis. J Bacteriol. 2006;188(14):5319-24. http://dx.doi.org/10.1128/JB.01662-05 PMid:16816208 PMCid:PMC1539956

16. Van der Giessen JWB, van de Giessen AW, Braks MAH. Emerging zoonoses: early warning and surveillance in the Netherlands. Bilthoven: Rijksinstituut voor Volksgezondheid en Milieu (RIVM). RIVM Rapport 330214002;2010;84.

17. Splettstoesser WD, Piechotowski I, Buckendahl A, Frangoulidis D, Kaysser P, Kratzer W, et al. Tularemia in Germany: the tip of the iceberg? Epidemiol Infect. 2009;137(5):736-43. http:// dx.doi.org/10.1017/S0950268808001192 PMid:18808726

18. Lutz W. Fallbericht, Landesbetrieb Wald und Holz. Forschungsstelle für Jagdkunde und Wildschadenverhütung FJW. Jagdjahr 2012/2013 [Roadkillreport, Landesbetrieb Wald und Holz, FJW, Huntingseason 2012/2013]. Landesbetrieb Wald und Holz Nordrhein-Westfalen. [Accessed 3 Dec 2013]. German. Available from: http://www.wald-und-holz.nrw.de/fileadmin/ media/Dokumente/Jagd/Fallwildkrankheiten/Informations PDF/Fallwildbericht_12_13.pdf

19. Avril A, Léonard Y, Letty J, Péroux R, Guitton J-S, Pontier D. Natal dispersal of European hare in a high density population. Mammalian Biology. 2011;76(2):148-6. http://dx.doi.org/10.1016/j.mambio.2010.07.001

20. Avril A, Letty J, Pradel R, Léonard Y, Santin-Janin H, Pontier D. A multi-event model to study stage-dependent dispersal in radio-collared hares: when hunting promotes costly transience. Ecology. 2012;93(6):1305-16.

http://dx.doi.org/10.1890/11-1742.1 PMid:22834372

21. Rijksinstituut voor Volksgezondheid en Milieu (RIVM), Staat van zoönosen 2011. [State of zoonotic diseases 2011]. Bilthoven: RIVM. RIVM Rapport 330291008;2012;40. Dutch.

22. Rijksinstituut voor Volksgezondheid en Milieu (RIVM), Patient in Nederland met tularemie. [Patient in the Netherlands with tularemia]. Bilthoven: RIVM. 15 Oct 2013. Dutch. Available from: http://www.rivm.nl/Documenten en publicaties/Algemeen_Actueel/Nieuwsberichten/2013/ Pati\%C3\%ABnt_in_Nederland_met_tularemie 